\title{
Fetal Cytokine Expression In Utero Detected by Reverse Transcriptase Polymerase Chain Reaction
}

\author{
JAMES N. JARVIS, LIANGPING DENG, STANLEY M. BERRY, ROBERTO ROMERO, ${ }^{1}$ AND \\ HEIDE MOORE \\ Department of Pediatrics, Wayne State University School of Medicine and the Children's Hospital of \\ Michigan, Detroit, Michigan 48201 [J.N.J., L.D., H.M.]; Department of Obstetrics/Gynecology, \\ Wayne State University School of Medicine [S.M.B., R.R.]
}

\begin{abstract}
Cytokine expression at the maternal-fetal interface is well documented. Some authors have postulated the existence of a bidirectional cytokine signaling mechanism that is critical to the maintenance of normal pregnancy. The role of the fetus (versus fetally derived placental tissues) in this process is unknown. Using reverse transcription polymerase chain reaction techniques, we studied paired maternal and fetal samples from 16 pregnancies (including two twin pregnancies) for the presence of tumor necrosis factor- $\alpha$ and IL- $1 \beta$ mRNA. We demonstrate that mRNA for both of these cytokines can be detected in both
\end{abstract}

ABSTRACT
Cytokine expression at the maternal-fetal interface is well documented (1). Developmental changes in levels of TNF- $\alpha$, IL-1 $\beta$, and IL- 6 have been described in both placental tissue and amniotic fluid (2), with significant rises in all three occurring at the time of labor. However, the precise role of any of these cytokines in cither maintaining normal pregnancy or initiating labor remains unknown. Wegmann and coworkers have suggested a critical role for cytokines in normal pregnancy, both for the maintenance of placental growth (3) and the modulation of maternal immune responses to prevent "rejection" of the semiallogenic conceptus (4). A central feature of Wegmann's hypothesis is that the cytokine interactions that characterize the maternal-fetal relationship are bidirectional and that both maternal and fetal (or fetally derived) tissues and cells participate in mutual regulatory responses (5).

The precise role of the fetus in the putative cytokine regulatory network of pregnancy has not been investigated. Abbas et al. (6) have demonstrated the presence of TNF- $\alpha$ in fetuses as early as 12 wk of gestation. TNF- $\alpha$ levels were higher in fetuses of greater gestational age, suggesting that fetal levels of this cytokine parallel those in amniotic fluid. However, al-

Received July 11, 1994; accepted December 10, 1994

James N. Jarvis, M.D., Department of Pediatrics, Division of Immunology/ Rheumatology, Children's Hospital of Michigan, 3901 Beaubien Blvd., Detroit, MI 48201 .

Supported by the Children's Hospital of Michigan Research Endowment Fund

${ }^{1}$ Current address: Perinatal Branch, National Institutes of Child Health and Human Development, 9000 Rockville Pike, Bldg. 31, Room 2A-46, Bethesda, MD 20892. maternal and fetal blood as early as the 21 st wk of gestation. These results support a potential role for the fetus in the bidirectional cytokine signaling of pregnancy. (Pediatr Res 37: 450454,1995 )
Abbreviations
PCR, polymerase chain reaction
rtPCR, reverse transcriptase polymerase chain reaction
TNF $\alpha$, tumor necrosis factor- $\alpha$

though these authors concluded that the TNF- $\alpha$ detected in fetal plasma was of fetal origin and coincided with the development of the fetal monocyte-macrophage system, the precise origin of the fetal plasma TNF- $\alpha$ could not be determined. It is equally possible that the TNF- $\alpha$ detected in fetal plasma was derived from placental or decidual cells, which communicate directly with the fetal circulation.

PCR techniques provide a convenient means of addressing issues related to the fetal cytokine repertoire. Although the presence of a specific cytokine in fetal plasma may not be conclusive evidence that the fetal immune system does secrete or is capable of secreting that cytokine (inasmuch as cytokines may pass from placental tissue to the fetus), the presence of cytokine mRNA in fetal blood cells would support the hypothesis that cytokinc expression occurs in the fetus as well as in placental tissue. The small amounts of RNA available in fetal blood specimens obtained by cordocentesis may yield considerable information about fetal cytokine mRNA transcripts and therefore the role of the fetus itself in the bidirectional cytokine signaling proposed by Wegmann et al. (5). We used rtPCR to examine maternal and fetal mRNA transcripts in the late second and third trimesters.

\section{METHODS}

Patients and patient specimens. Specimens from 16 pregnancies were studied. In two cases, blood from the mother and from each fetus of a twin pregnancy was available for study 
(therefore, 16 mothers and 18 fetuses were studied). Blood was obtained by cordocentesis from fetuses at 21 to $39 \mathrm{wk}$ of gestation after prior written informed consent was obtained from the mothers. The procedure for cordocentesis has previously been described (7). Gestational ages of fetuses and indications for cordocentesis are given in Table 1. Samples were drawn into sterile EDTA tubes and carried to the laboratory. Plasma was separated from cells by centrifugation, and cell pellets were stored at $-70^{\circ} \mathrm{C}$ until used.

Isolation of RNA from whole blood. RNA was isolated from whole blood by a method modified from that described by Chomczynski and Sacchi (8). Two hundred $\mu \mathrm{L}$ of whole blood were placed in $500 \mu \mathrm{L}$ of denaturing solution consisting of 4.0 $\mathrm{M}$ guanidinium thiocyanate, $25 \mathrm{mM}$ sodium citrate, $0.5 \%$ sodium N-laurosarcosine, and 0.1 M 2-mercaptoethanol, with $20 \mu \mathrm{g}$ polyinosinic acid used as carrier RNA. Samples were vortexed and $200 \mu \mathrm{L}$ of $95 \%$ ethanol added. Samples were then placed on ice for $5 \mathrm{~min}$ and subjected to centrifugation in a microfuge at $10000 \times g$ for $15 \mathrm{~min}$ at $4^{\circ} \mathrm{C}$. Supernates were discarded and pellets dissolved in $150 \mu \mathrm{L}$ of denaturing solution and $15 \mu \mathrm{L}$ of $2.0 \mathrm{M}$ sodium acetate, $\mathrm{pH} 4.2$. Solubilized pellets were then incubated on ice for $10 \mathrm{~min}$ with an equal volume of phenol-chloroform solution $(10: 4 \mathrm{vol} / \mathrm{vol})$ and subjected to centrifugation at $10000 \times \mathrm{g}$ for $15 \mathrm{~min}$ at $4^{\circ} \mathrm{C}$. The aqueous phase was saved and precipitated with an equal volume of isopropyl alcohol, with samples incubating at $-20^{\circ} \mathrm{C}$ for $30 \mathrm{~min}$. After incubation, samples were centrifuged at $10000 \times g$ for $15 \mathrm{~min}$ at $4^{\circ} \mathrm{C}$ and supernatants discarded. Pelleted RNA was washed once with $75 \%$ ethanol and dissolved in sterile water with $0.1 \%$ diethylprocarbinate. RNA was either frozen at $-20^{\circ} \mathrm{C}$ or used immediately for reverse transcription reactions.

Reverse transcription of RNA to DNA. Reverse transcription of RNA to DNA was accomplished with Moloney murine leukemia virus reverse transcriptase and random hexamer primers using commercially available reagents (GeneAmp, Perkin Elmer Cetus, Norwalk, CT). Conditions for reverse transcription were $50 \mathrm{mM} \mathrm{KCl}, 10 \mathrm{mM}$ Tris- $\mathrm{HCl}$ (pH 8.3), 5.0

Table 1. Patients, gestational age, and indications for cordocentesis

\begin{tabular}{ccl}
\hline Patient & $\begin{array}{c}\text { Gestational } \\
\text { age (wk) }\end{array}$ & \multicolumn{1}{c}{ Indications } \\
\hline 1 & 23 & Polyhydramnios \\
2 & 24 & Renal dysplasia \\
3 & 29 & Polyhydramnios \\
4 & 29 & Primary CMV infection \\
5 & 31 & Rh incompatibility \\
6 & 39 & Primary CMV infection \\
7 & 33 & Premature rupture of membranes \\
8 & 36 & Intrauterine growth retardation \\
9 & 26 & Intrauterine growth retardation \\
10 & 36 & Discordant twins \\
11 & 21 & Discordant twins \\
12 & 22 & Primary varicella infection \\
13 & 23 & Intrauterine growth retardation \\
14 & 32 & Preterm labor \\
15 & 23 & Polyhydramnios \\
16 & 34 & Preterm labor \\
\hline
\end{tabular}

CMV, cytomegalovirus.
$\mathrm{mM} \mathrm{MgCl} 2,1.0 \mathrm{mM}$ each deoxynucleotriphophates, $2.5 \mu \mathrm{M}$ random hexamers, $2.5 \mathrm{U} / \mu \mathrm{L}$ reverse transcriptase, and 1.0 $\mathrm{U} / \mu \mathrm{L}$ RNase inhibitor with $2.0 \mu \mathrm{L}$ of target RNA in a total volume of $20 \mu \mathrm{L}$. Reactions were performed in a single three-step cycle: $42^{\circ} \mathrm{C}$ for $15 \mathrm{~min}, 99^{\circ} \mathrm{C}$ for $5 \mathrm{~min}$, and $5^{\circ} \mathrm{C}$ for $5 \mathrm{~min}$. DNA generated from this process was either stored at $-20^{\circ} \mathrm{C}$ or used immediately for PCR experiments to detect specific cytokine mRNA.

PCR and agarose gel electrophoresis to detect cytokine $m R N A$. Oligonucleotide primers for TNF- $\alpha$, IL- $1 \beta$, and $\beta$-actin were obtained from a commercial source (Clontech, Palo Alto, CA). Sequences of the $5^{\prime}$ and $3^{\prime}$ primers for each cytokine are given in Table 2. Amplification reactions were accomplished with Thermus aquaticus DNA polymerase (2.0 $\mathrm{U}$ per reaction) in $50 \mathrm{mM} \mathrm{KCl}, 10 \mathrm{mM}$ Tris- $\mathrm{HCl}, 1.5 \mathrm{mM}$ $\mathrm{MgCl}_{2}, 0.2 \mathrm{mM}$ deoxynucleotriphophates, $0.4 \mu \mathrm{M} 5^{\prime}$ and $3^{\prime}$ primers, with $5.0 \mu \mathrm{L}$ of target DNA in a volume of $50 \mu \mathrm{L}$. Cycling was performed at $94^{\circ} \mathrm{C}$ for $45 \mathrm{~s}$ for denaturation, $60^{\circ} \mathrm{C}$ for $45 \mathrm{~s}$ for annealing, and $72^{\circ} \mathrm{C}$ for $2 \mathrm{~min}$ for elongation for 35 cycles. This program was linked to single $72^{\circ} \mathrm{C}(7 \mathrm{~min})$ and $4^{\circ} \mathrm{C}$ cycles. Samples were then solubilized in $6 \times$ buffer consisting of $0.25 \%$ bromphenol blue, $0.25 \%$ xylene cyanol, and $30 \%$ glycerol and subjected to electrophoresis in 1.8\% agarose-ethidium bromide gels. Gels were examined for bands of appropriate molecular weight and compared with a positive control generated from a cDNA fragment provided with the primer sets encompassing the sequences amplified in the PCR process. $\beta$-actin was also used as a positive control and to determine the efficiency of RNA isolation and cDNA amplification.

Southern blot analysis of amplified PCR products. In selected cases, verification of the identity of the PCR product was performed using Southern blot analysis using commercially available cDNA probes for the sequences amplified in the PCR reactions (Clontech, Palo Alto, CA). Probes were labeled with horseradish peroxidase using commercially available reagents (ECL chemiluminescence detection system, Amersham, Arlington Heights, IL). PCR products were transferred to nylon membranes by capillary action overnight in $1.5 \mathrm{M} \mathrm{NaCl}$ and $0.5 \mathrm{M} \mathrm{NaOH}$. Prehybridization and hybridization of the labeled probes were performed exactly according to the manufacturer's specifications. Signal was generated from the labeled probes by the addition of the detection reagent provided with the labeling kit. Membranes were exposed to Kodak XAR film for times varying from $30 \mathrm{~s}$ to $5 \mathrm{~min}$, and the resultant luminograms were examined for bands corresponding to the positive control generated as described above.

\section{RESULTS}

Results from these experiments are summarized in Table 3. The agarose gel from a typical PCR analysis of maternal and fetal blood samples is shown in Figure 1. TNF- $\alpha$ mRNA was assayed in 16 maternal-fetal pairs. TNF- $\alpha$ mRNA was detected in all 18 fetal blood samples and in 15 of the 16 maternal samples. Although ethidium bromide-stained bands for fetal TNF- $\alpha$ were generally more prominent than bands from maternal samples, this was probably due to the more efficient 
Table 2. Sequences of primers used for reverse transcriptase PCR

\begin{tabular}{ll}
\hline -Actin & \\
Upstream (5') & 5' ATC TGG CAC CAC ACC TTC TAC AAT GAG CTG CG 3' \\
Downstream (3') & 5' CGT CAT ACT CCT GCT TGC TGA TCC ACA TCT GC 3' \\
IL-1 $\beta$ & 5' ATG GCA GAA GTA CCT AAG CTC GC 3' \\
Upstream (5') & 5' A CAC AAA TTG CAT GGT GAA GTC AGT T 3' \\
Downstream (3') & \\
TNF $\alpha$ & GAG TGA CAA GCC TGT AGC CCA TGT TGT AGC A 3' \\
Upstream (5') & GCA ATG ATC CCA AAG TAG ACC TGC CCA GAC T 3' \\
\hline
\end{tabular}

Table 3. Results of cytokine rtPCR assays*

\begin{tabular}{cccccc} 
& \multicolumn{3}{c}{ TNF $\alpha$} & & \multicolumn{3}{c}{ IL-1 $\beta$} \\
\cline { 2 - 5 } Paticnt & Mother & Fetus & Mother & Fetus \\
\hline 1 & + & + & ND & ND \\
2 & + & + & ND & ND \\
3 & + & + & ND & ND \\
4 & + & + & Neg & + \\
5 & + & + & + & + \\
6 & + & + & + & + \\
7 & + & + & + & + \\
8 & Neg & + & + & + \\
9 & + & + & + & + \\
$10 \dagger$ & + & $+1+$ & + & $+1+$ \\
11 & + & + & + & + \\
12 & + & + & & \\
13 & + & + & + & + \\
$14+$ & + & $+/+$ & Neg & Neg/Neg \\
15 & + & + & Neg & Neg \\
16 & + & + & Neg & Neg \\
\hline
\end{tabular}

ND, not donc; Neg, negative.

*All samples were positive for $\beta$-actin.

$\uparrow$ Twin pregnancy.

RNA isolation from fetal blood (which contains more nucleated cells in a given volume than maternal blood), inasmuch as $\beta$-actin bands tended to be brighter in these same samples (Fig. $1 A)$. The $\beta$-actin band in the mother with undetectable TNF- $\alpha$ mRNA was strongly positive, confirming that the RNA isolation, reverse transcription, and PCR were as efficient as in the other maternal samples.

PCR analysis for IL- $1 \beta$, which was examined in 13 pregnancies, showed a different pattern (Fig. 2). In three pregnancies (including one of the twin pregnancies), IL-1 $\beta$ was clearly negative. One pregnancy showcd discordance in IL- $1 \beta$ expression between mother and fetus, with the fetus showing a faint IL-1 $\beta$ band and the mother negative. In two other maternalfetal pairs, faint bands for IL- $1 \beta$ were produced by PCR. In seven pregnancies, IL-1 $\beta$ was clearly positive.

Expression of IL- $1 \beta$ may have been related to fetal exposure to viral infection, inasmuch as mRNA for this cytokine was clearly positive in the 22-wk fetus (and mother) with maternal varicella infection (patient 12), whereas weak bands were seen in both of the infants exposed to primary maternal cytomegalovirus infection. Because no attempt was made to make the PCR assays quantitative or even semiquantitative, no conclusions can be drawn regarding the level of TNF- $\alpha$ or IL- $1 \beta$ mRNA expression and specific clinical situations (e.g. intrauterine growth retardation).

\section{DISCUSSION}

The discovery that TNF- $\alpha$, IL- $1 \beta$, and IL- 6 are expressed at the maternal-fetal interface has generated considerable interest in their role in pregnancy and the initiation of labor. Wegmann et al. (5) have suggested that normal pregnancy requires a bidirectional, intercommunicating cytokine network that includes the maternal immune system and fetally derived placental tissues, especially placental trophoblasts (4). Whether the fetus plays any role in this network is unknown. The finding of TNF- $\alpha$ in fetal plasma as described by Abbas et al. (6) was supportive of a role for the fetus in this process. Howcver, monocytes obtained from both term and preterm infants postnatally have been shown to have little constitutive expression of either IL- $1 \beta$ or TNF- $\alpha$, although such cells will respond to bacterial lipopolysaccharide to produce IL- $1 \beta$ and, to a lesser extent, TNF- $\alpha$ (9).

We have presented strong evidence for fetal cytokine mRNA expression in utero as early as $21 \mathrm{wk}$ of gestation. The specific cytokines detected, TNF- $\alpha$ and IL-1 $\beta$, are most commonly expressed in cells of the monocyte/macrophage lineage and suggest that this portion of the immune system is already well developed by the second trimester. Why these cells transcribe low levels of TNF- $\alpha$ and IL-1 $\beta$ mRNA during fetal life is unclear. Although it is possible that low levels of mRNA for these cytokines may be detected in resting monocytes in normal infants or children (a question that we are currently addressing), it is also possible that expression of these cytokines reflects fetal participation in the so-called cytokine network of pregnancy. Alternatively, it could reflect the fact that the monocyte-macrophage system in the fetus is in an activated state due to rapid growth and differentiation. A similar hypothesis has been suggested for fetal $\mathrm{T}$ cells, a high percentage of which express the activation marker CD38 (7).

We have considered the possibility that the TNF- $\alpha$ and IL-1 $\beta$ mRNA amplified from cordocentesis specimens may have come from a few contaminating amniotic fluid cells. However, levels of fetal mRNA were, if anything, higher than the amount of mRNA from maternal blood. It therefore seems very unlikely that the cytokine mRNA amplified from the fetal samples came from anywhere but fetal blood.

We believe that PCR technology will be an important tool in the understanding of the immunobiology of the fetus and pregnancy, particularly in investigating the role of cytokines. Because most cytokines are secreted and act locally, and because expression of many cytokines is accompanied by expression of soluble receptors and inhibitors, there are serious 


\section{A TNF $\alpha$}

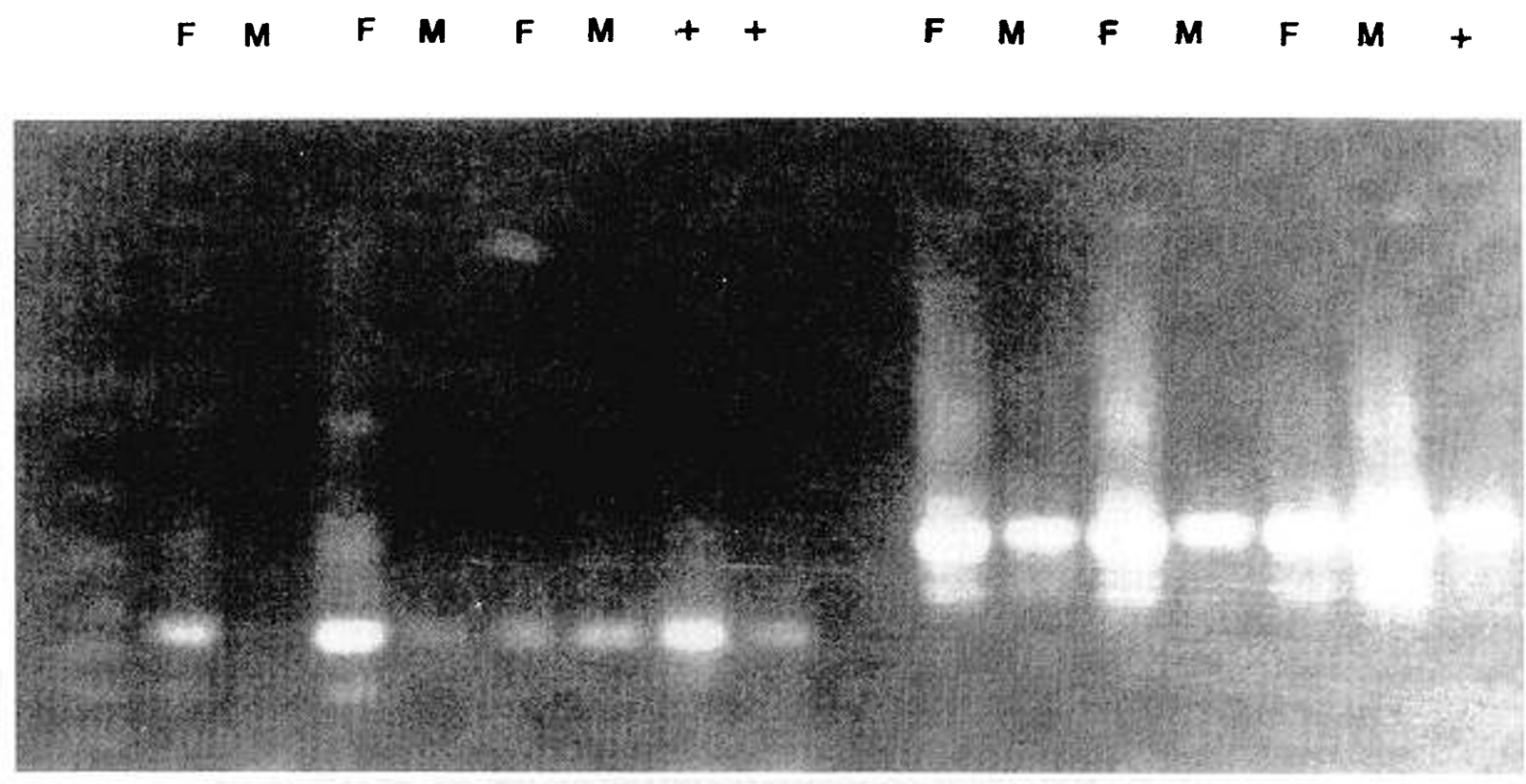

B

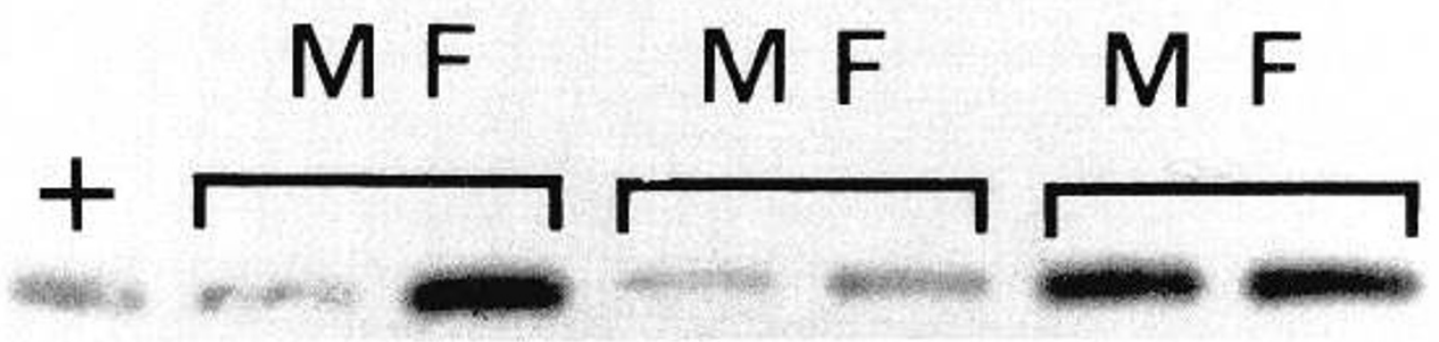

Figure 1. A, Ethidium bromide-stained agarose gel showing amplified products from threc maternal fetal-pairs (patients 1,2, and 3). TNF- $\alpha$ is shown on the left and $\beta$-actin on the right. Fetal $(F)$ and maternal $(M)$ samples are designatcd. Positive control lanes are designated " + ". Although signals from the fetal TNF- $\alpha$ samples secm to be stronger than those from maternal samples, this may have been caused by the larger amount of RNA isolated from fetal whole blood: $\beta$-actin bands were also slightly brighter in fetal samples. $B$, Southern blot analysis of DNA products generated from rtPCR analysis for TNF- $\alpha$ in three maternal-fctal pairs (Patients 14, 15, and 16).

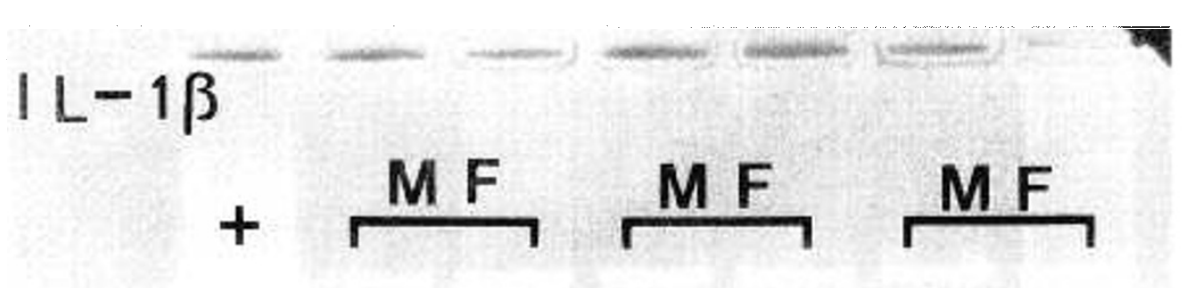

Figure 2. Representative ethidium bromide/agarose gel showing rtPCR analysis for IL-1 $\beta$ in blood samples from thrce matcrnal-fetal pairs. Shown here are the three maternal-fetal pairs that were most strikingly positive for IL-1 $\beta$ (Patients $11,12,13$ ). Maternal $(M)$ and fetal $(F)$ samples as well as positive controls $(+)$ are designated. 
pitfalls in the measurement of these proteins in plasma by either bioassay or immunologic methods. The use of rtPCR, however, provides a sensitive, specific, and even quantitative method (10) for examining cytokine expression in vivo or in vitro. These techniques, coupled with our increasing ability to sample fetal tissue in vivo, provide the opportunity for significant advances in our understanding of fetal immunobiology in the near future.

Acknowledgments. The authors thank Rui Yan, who provided valuable technical advice, and Dr. Sanford Cohen, who reviewed the manuscript and provided his considerable insight and encouragement.

\section{REFERENCES}

1. Kauma S, Matt D, Strom S, Eierman D, Turner T 1990 Interleukin $1 \beta$, human leukocyte antigen HLA-DR $\alpha$, and transforming growth factor $\beta$ expression in endomctrium, placenta, and placental membranes. Am J Obstet Gynecol 163:1430-1437
2. Opsjøn S-L, Wathen NC, Tingulstad S, Wiedswang G, Sundan A, Waage A, Austgulen R 1993 Tumor necrosis factor, interleukin 1 , and interleukin 6 in normal pregnancy. Am J Obstet Gynecol 169:397-404

3. Wegmann TG, Guilbert LJ 1992 Immune signalling at the maternal-fetal interface and trophoblastic differentiation. Dev Comp Immunol 16:425-430

4. Guilbert L, Robertson SA, Wegmann TG 1993 The trophoblast as an integral component of a macrophage-cytokine network. Immunol Cell Biol 71:49-57

5. Wegmann TG, Lin H, Guilbert L, Mosmann TR 1993 Bidirectional cytokine interactions in the matcrnal-fetal relationship: is successful pregnancy a $\mathrm{T}_{\mathrm{H}} 2$ phenomenon? Immunol Today 7:353-356

6. Abbas A, Snijders RJ, Buggins AG, Layton DM, Nicolaides KH 1993 Fetal plasma tumor necrosis factor concentration in normal pregnancy. Fetal Diagn Ther 8:220-223

7. Berry SB, Fine N, Bichalski JA, Cotton DB, Dombrowski MP, Kaplan J 1993 Circulating lymphocyte subsets in second- and third-trimester fetuses: comparison with newborns and adults. Am J Obstet Gynecol 167:895-900

8. Chomczynski P, Sacchi N 1987 Single-step method of RNA isolation by acid guanidinium thiocyanate-phenol-chloroform extraction. Anal Biochem 162:156-159

9. Weatherstone KB, Rich EA 1989 Tumor necrosis factor/cachectin and interleukin-1 secretion by cord blood monocytes from premature and term neonates. Pediatr Res 25:342-346

10. Lathey JL, Kanangat S, Rouse BT 1994 Differential expression of tumor necrosis factor $\alpha$ and interleukin $1 \beta$ compared with interleukin 6 in monocytes from human immunodeficiency virus-positive individuals measured by polymerase chain reaction. J Acquir Immunc Defic Syndr 7:109-115 